\title{
Long-term changes in tropospheric ozone
}

\author{
S.J. Oltmans ${ }^{\mathrm{a}, *}$, A.S. Lefohn ${ }^{\mathrm{b}}$, J.M. Harris ${ }^{\mathrm{a}, \mathrm{c}}$, I. Galbally ${ }^{\mathrm{d}}$, H.E. Scheel ${ }^{\mathrm{e}}$, \\ G. Bodeker ${ }^{\mathrm{f}}$, E. Brunke ${ }^{\mathrm{g}}$, H. Claude ${ }^{\mathrm{h}}$, D. Tarasick ${ }^{\mathrm{i}}$, B.J. Johnson ${ }^{\mathrm{a}}$, P. Simmonds ${ }^{\mathrm{j}}$, \\ D. Shadwick ${ }^{k}$, K. Anlauf ${ }^{i}$, K. Hayden ${ }^{\mathrm{i}}$, F. Schmidlin', T. Fujimoto ${ }^{\mathrm{m}}$, K. Akagim ${ }^{\mathrm{m}}$,

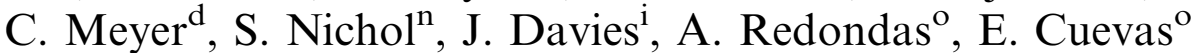 \\ ${ }^{a}$ NOAA Earth System Research Laboratory, Global Monitoring Division, 325 Broadway, Boulder, CO 80305, USA \\ ${ }^{\mathrm{b}}$ A.S.L. \& Associates, Helena, MT 59601, USA \\ ${ }^{\mathrm{c}} \mathrm{STC}$ Corporation, Boulder, CO 80303, USA \\ ${ }^{\mathrm{d}}$ CSIRO Atmospheric Research, Aspendale, Victoria, Australia \\ ${ }^{\mathrm{e}}$ Forschungzentrum Karlsruhe, IMK-IFU, Garmisch-Partenkirchen, Germany \\ ${ }^{\mathrm{f}}$ NIWA, Lauder Observatory, New Zealand \\ ${ }^{\mathrm{g}}$ South African Weather Service, Stellenbosch, South Africa \\ ${ }^{\mathrm{h}}$ Deutscher Wetterdienst, Observatorium Hohenpeissenberg, Germany \\ ${ }^{\mathrm{i}}$ Meteorological Service of Canada/Environment Canada, Toronto, Ont., Canada \\ ${ }^{\mathrm{j}}$ School of Chemistry, University of Bristol, UK \\ ${ }^{\mathrm{k}} 320$ Eastwood Road, Chapel Hill, NC 27514, USA \\ ${ }^{1} N A S A / G S F C$ Wallops Flight Facility, VA, 23337, USA \\ ${ }^{\mathrm{m}}$ Japan Meteorological Agency, Tokyo, Japan \\ ${ }^{\mathrm{n}}$ NIWA, Wellington, New Zealand \\ ${ }^{\circ} I M N$, Observatorio Atmosphérico de Izaña, Santa Cruz de Tenerife, Spain
}

Received 30 September 2005; received in revised form 18 January 2006; accepted 18 January 2006

\begin{abstract}
Tropospheric ozone changes are investigated using a selected network of surface and ozonesonde sites to give a broad geographic picture of long-term variations. The picture of long-term tropospheric ozone changes is a varied one in terms of both the sign and magnitude of trends and in the possible causes for the changes. At mid latitudes of the S.H. three time series of $\sim 20$ years in length agree in showing increases that are strongest in the austral spring (August-October). Profile measurements show this increase extending through the mid troposphere but not into the highest levels of the troposphere.

In the N.H. in the Arctic a period of declining ozone in the troposphere through the 1980s into the mid-1990s has reversed and the overall change is small. The decadal-scale variations in the troposphere in this region are related in part to changes in the lowermost stratosphere.

At mid latitudes in the N.H., continental Europe and Japan showed significant increases in the 1970s and 1980s. Over North America rises in the 1970s are less than those seen in Europe and Japan, suggesting significant regional differences. In all three of these mid latitude, continental regions tropospheric ozone amounts appear to have leveled off or in some cases declined in the more recent decades. Over the North Atlantic three widely separated sites show significant increases since the late-1990s that may have peaked in recent years.
\end{abstract}

\footnotetext{
*Corresponding author. Tel.: + 13034976676 ; fax: + 13034975590.

E-mail address: samuel.j.oltmans@noaa.gov (S.J. Oltmans).
} 
In the N.H. tropics both the surface record and the ozonesondes in Hawaii show a significant increase in the autumn months in the most recent decade compared to earlier periods that drives the overall increase seen in the 30-year record. This appears to be related to a shift in the transport pattern during this season with more frequent flow from higher latitudes in the latest decade.

(C) 2006 Elsevier Ltd. All rights reserved.

Keywords: Trends; Surface ozone; Ozonesondes; Tropospheric chemistry; Ozone transport

\section{Introduction}

Ozone in the troposphere is a key ingredient in a number of atmospheric physical and chemical processes. These include radiative forcing as ozone is an infrared absorber (greenhouse gas). It is also a precursor to the formation of the hydroxyl radical which affects the oxidizing (cleansing) capacity of the atmosphere. Tropospheric ozone is an effective absorber of solar ultraviolet (UV) radiation that on a per molecule basis is more effective than stratospheric ozone in filtering UV-B (Bruhl and Crutzen, 1989). The larger tropospheric column ozone amounts in the N.H. as compared to the S.H. may be an important contributor to the larger surface UV amounts recorded in the S.H. (McKenzie et al., 2003). In addition, human health, terrestrial ecosystems, and materials degradation are impacted by poor air quality resulting from high ozone levels caused by photochemical ozone production of human-emitted precursors. Tropospheric ozone changes may also come about from climate changes, such as an increase in stagnation episodes or other altered transport patterns. While air quality concerns are focused near ground level, the climatic and oxidizing impacts of tropospheric ozone are significant through the entire depth of the troposphere.

Determination of the long-term changes in tropospheric ozone on a global or hemispheric basis is hampered by the relative scarcity of representative observing locations with observational records of 15 years or more. With a lifetime of several days to several weeks, ozone is not a globally or even hemispherically well-mixed constituent of the troposphere. Representative observations on geographic scales of 500-1000 km (Prinn, 1988) are required for characterizing ozone behavior in background air on a regional basis. While surface ozone is extensively observed at sites in N.H. continental regions as part of air quality monitoring networks, these sites are often only representative of local conditions. Profile measurements that include the troposphere are very limited spatially and are carried out relatively infrequently (in most cases weekly). In the S.H. measurements are limited but with fewer continental regions with large precursor emissions, the tropospheric ozone distribution may present a more homogeneous picture than in the N.H. Even with these notable limitations it is useful to examine the available time series to get as broad a picture as possible of changes that are occurring. It is changes on these larger scales that may play the biggest role in climate forcing and oxidizing capacity by tropospheric ozone. Several earlier studies have addressed changes in tropospheric ozone with the focus on developing as broad a picture as possible of the geographic distribution of these changes (Logan, 1994; Logan et al., 1999; Oltmans et al., 1998; Vingarzan, 2004). This work builds on the analysis of Oltmans et al. (1998) by extending many of the time series, supplementing with additional locations, and using several new statistical tools to do this analysis.

The approach taken in this study is to focus on tropospheric ozone time series with relatively long records (mostly 15 years or longer) and locations (Table 1) that are representative of large geographic regions not immediately influenced by nearby precursor sources. We designate these sites as "background" stations. This designation is somewhat arbitrary but considers distance from precursor sources and the character of ozone variation at the site. In some cases a degree of compromise is made in these criteria because of the longevity of a record at a key location. In discussing the record from a particular site, the potential departure from background characteristics is considered. Data from surface measuring sites are drawn primarily from two sources. Most of the remote or high-altitude sites are part of the World Meteorological Organization (WMO) Global Atmosphere Watch (GAW) network and data are available from the World Data Centre for Greenhouse Gases (WDCGG). Several North American sites are located in US National Parks and the data come from the US EPA Air Quality System (AQS) data archive. The 
Table 1

Locations, period of observation, and type of observation (surface or ozonesonde) for stations used in this study

\begin{tabular}{|c|c|c|c|c|c|}
\hline Station & Lat. & Lon. & Elev (m) & Period & Type \\
\hline Alert, Nunavut, Canada & $82.5 \mathrm{~N}$ & $62.3 \mathrm{~W}$ & 62 & $\begin{array}{l}1992-2004 \\
1987-2004\end{array}$ & $\begin{array}{l}\text { Surface } \\
\text { Ozonesonde }\end{array}$ \\
\hline Resolute, NWT, Canada & $74.7 \mathrm{~N}$ & $95.0 \mathrm{~W}$ & 64 & $1980-2003$ & Ozonesonde \\
\hline Barrow, Alaska, USA & $71.1 \mathrm{~N}$ & $156.6 \mathrm{~W}$ & 11 & 1973-2004 & Surface \\
\hline Denali NP, Alaska, USA & $63.7 \mathrm{~N}$ & $149.0 \mathrm{~W}$ & 661 & $1987-2003$ & Surface \\
\hline Churchill, Manitoba, Canada & $58.8 \mathrm{~N}$ & $94.1 \mathrm{~W}$ & 35 & 1980-2004 & Ozonesonde \\
\hline Edmonton, Alberta, Canada & $53.6 \mathrm{~N}$ & $114.1 \mathrm{~W}$ & 766 & 1979-2004 & Ozonesonde \\
\hline Goose, Newfndlnd, Canada & $53.3 \mathrm{~N}$ & $60.3 \mathrm{~W}$ & 44 & 1979-2004 & Ozonesonde \\
\hline Mace Head, Ireland & $53.2 \mathrm{~N}$ & $9.54 \mathrm{~W}$ & 25 & $1987-2003$ & Surface \\
\hline Glacier NP, Montana, USA & $48.5 \mathrm{~N}$ & $114.0 \mathrm{~W}$ & 976 & 1989-2003 & Surface \\
\hline Olympic NP, Wash., USA & $48.1 \mathrm{~N}$ & $123.3 \mathrm{~W}$ & 125 & $1987-2003$ & Surface \\
\hline Hohenpeissenberg, Germany & $47.8 \mathrm{~N}$ & $11.0 \mathrm{E}$ & 975 & 1966-2004 & Ozonesonde \\
\hline Zugspitze, Germany & $47.4 \mathrm{~N}$ & $11.0 \mathrm{E}$ & 2962 & 1978-2004 & Surface \\
\hline Whiteface Mtn., NY, USA & $44.4 \mathrm{~N}$ & $73.9 \mathrm{~W}$ & 1484 & 1973-2004 & Surface \\
\hline Sapporo, Japan & $43.1 \mathrm{~N}$ & $141.3 \mathrm{E}$ & 19 & $1967-2004$ & Ozonesonde \\
\hline Yreka, California, USA & $41.7 \mathrm{~N}$ & $122.6 \mathrm{~W}$ & 800 & $1981-2003$ & Surface \\
\hline Lassen NP, Calif., USA & $40.5 \mathrm{~N}$ & $121.6 \mathrm{~W}$ & 1756 & $1987-2003$ & Surface \\
\hline Boulder, Colorado, USA & $40.0 \mathrm{~N}$ & $105.0 \mathrm{~W}$ & 1745 & 1979-2004 & Ozonesonde \\
\hline Wallops Isl., Virginia, USA & $37.9 \mathrm{~N}$ & $75.5 \mathrm{E}$ & 13 & $1970-2003$ & Ozonesonde \\
\hline Tsukuba (Tateno), Japan & $36.1 \mathrm{~N}$ & $140.1 \mathrm{E}$ & 31 & 1968-2004 & Ozonesonde \\
\hline Tudor Hill, Bermuda & $32.3 \mathrm{~N}$ & $64.9 \mathrm{~W}$ & 30 & 1988-2004 & Surface \\
\hline Kagoshima, Japan & $31.6 \mathrm{~N}$ & $130.6 \mathrm{E}$ & 31 & 1968-2004 & Ozonesonde \\
\hline Izaña, Tenerife, Spain & $28.3 \mathrm{~N}$ & $16.5 \mathrm{~W}$ & 2800 & 1988-2004 & Surface \\
\hline Naha, Japan & $26.2 \mathrm{~N}$ & $127.7 \mathrm{E}$ & 27 & 1989-2004 & Ozonesonde \\
\hline Hilo, Hawaii, USA & $19.7 \mathrm{~N}$ & $155.1 \mathrm{~W}$ & 11 & 1982-2004 & Ozonesonde \\
\hline Mauna Loa, Hawaii, USA & $19.5 \mathrm{~N}$ & $155.6 \mathrm{~W}$ & 3397 & 1973-2004 & Surface \\
\hline Matatula Pt., Am. Samoa & $14.3 \mathrm{~S}$ & $170.6 \mathrm{~W}$ & 82 & 1975-2004 & Surface \\
\hline Pago Pago, American Samoa & $14.5 \mathrm{~S}$ & $170.5 \mathrm{~W}$ & 10 & 1986-2004 & Ozonesonde \\
\hline Cape Point, South Africa & $34.4 \mathrm{~S}$ & $18.5 \mathrm{E}$ & 230 & 1983-2004 & Surface \\
\hline Cape Grim, Australia & $40.7 \mathrm{~S}$ & $144.7 \mathrm{E}$ & 104 & 1982-2004 & Surface \\
\hline Baring Head, New Zealand & $41.4 \mathrm{~S}$ & $174.9 \mathrm{E}$ & 85 & $1991-2003$ & Surface \\
\hline Lauder, New Zealand & $45.0 \mathrm{~S}$ & $169.7 \mathrm{E}$ & 370 & 1986-2004 & Ozonesonde \\
\hline Syowa, Antarctica & $69.0 \mathrm{~S}$ & $39.6 \mathrm{E}$ & 21 & 1966-2004 & Ozonesonde \\
\hline \multirow[t]{2}{*}{ South Pole, Antarctica } & $90.0 \mathrm{~S}$ & - & 2840 & 1975-2004 & Surface \\
\hline & & & & 1986-2004 & Ozonesonde \\
\hline
\end{tabular}

vertical profile measurements are from balloonborne ozonesondes. These observations are some of the longest records of tropospheric ozone. Many of these sites are also part of the GAW network and the data are available from the World Ozone and Ultraviolet Radiation Data Centre (WOUDC). Investigators associated with most of the surface and ozonesonde data sets are part of this study. The following sections will discuss the measurement methods and data sets to be used in the analysis, the statistical models used in the treatment of the observations, a presentation of the trend results, and a discussion of the pattern of long-term changes and in some cases possible keys to understanding tropospheric ozone changes. Tropospheric ozone changes are investigated using a selected series of surface and ozonesonde sites to give a broad geographic picture of longer-term variations. The longest time series are nearly 40 years in length with the majority of records extending back about 20 years.

\section{The measurements}

\subsection{Surface observations}

Most of the surface measurements used in this study were obtained using continuously operating analyzers that are based on the absorption of UV radiation at $254 \mathrm{~nm}$ in a cell of known length (Meyer et al., 1990). For the most part the ozone analyzers are referenced to a standard instrument 
also employing the UV absorption technique. These references are traceable to the Standard Reference Photometer (SRP) maintained by the US National Institute of Standards and Technology (NIST). In recent years this standard has been propagated in the GAW network through the Swiss operated WMO World Calibration Centre for Surface Ozone, which also maintains an SRP. The US National Park instruments as well as other data sets in the US EPA archive are linked to the NIST standard through EPA maintained SRPs. The traceability of the calibration of the data sets is not likely as well documented in the 1970s as in more recent years. The long-term stability of these time series has in most cases been maintained at a level of $\sim \pm 2 \%$.

\subsection{Ozonesondes}

Ozone profile measurements are obtained using balloon-borne ozonesondes that obtain a snapshot of the atmosphere, usually on a weekly schedule. A notable exception is the sounding program at Hohenpeissenberg in southern Germany where soundings were made once per week beginning in the late-1960s, but have been made 2-3 times per week since 1978. In the records considered here, three different types of ozonesondes were used, all employing some variation of the reaction of ozone with potassium iodide. At Hohenpiessenberg the Brewer-Mast ozonesonde (Brewer and Milford, 1960) has been used throughout the measurement period using procedures (Claude et al., 1987) that have produced a high-quality time series. At the Japanese station the KC type sonde was used that was converted in 1979 from a two-chamber electrochemical concentration cell (ECC) to a single cell instrument (SPARC, 1998). The time series at the Japanese stations have significant periods with infrequent soundings particularly in the late-1970s and through the 1980s. The other locations used in this study employed the ECC ozonesonde (Komhyr, 1969) that has been extensively evaluated (Johnson et al., 2002; Smit and Straeter, 2004). The measurement uncertainties influencing trends for tropospheric observations with ozonesondes is of the order of $2 \%$ /decade (SPARC, 1998).

\subsection{Back trajectories}

To help identify the role that changing transport patterns may play on long-term ozone changes, clustered air parcel trajectories were examined. In this study 3-dimensional (3-D) back trajectories were calculated using the European ERA-40 Reanalysis Data Set (http://www.ecmwf.int/research/ era). The characteristics, including the strengths and weaknesses, of various trajectory formulations are discussed in Harris et al. (2005).

\section{Treatment of the data}

Several approaches have been used to analyze the time-varying characteristics of the tropospheric ozone time series. The seasonal dependence of the trends has been deduced by separately analyzing calendar monthly averages of the data records. In addition, to highlight the decadal changes in these seasonally dependent trends, the trends have been examined for three decadal periods: 1995-2004, 1985-1994 and 1975-1984, the last of which may have a different start year depending on the data record analyzed. For Hohenpeissenberg the segment from the beginning of the record in 1966 to 1974 was also considered.

To examine the linear trend in each of the 12 calendar monthly mean time series, the following equation is used:

Ozone $=\tau t+\beta+$ residual,

where $\tau$ is the monthly trend parameter and $\beta$ is the monthly intercept parameter. An autoregressive process of order two (AR(2)) error structure for the residual term was used (Tiao et al., 1990).

The monthly change in the distribution of hourly average concentrations for each monitoring site was investigated by characterizing the median difference between each $10 \mathrm{ppb}$ increment in absolute frequency except at the South Pole background site where increments of $5 \mathrm{ppb}$ were used. These median differences for each increment (10 or $5 \mathrm{pbb}$ ) are plotted as histograms. To test for statistical significance, Kendall's tau test (Lefohn and Shadwick, 1991) was used to determine significance at the $10 \%$ level for the specified increments. The overall ozone trend is computed in a two-step process (Harris et al., 2001). The first step uses an autoregressive model that incorporates explanatory variables and a cubic polynomial fit rather than a straight line for better representation of the longterm variations. The model accounts for serial correlation in the ozone data and minimizes the residual variance of the model fit by regressing to known sources of ozone variability. The second step 
determines the ozone tendency (trend line) and growth rate curves (Thoning et al., 1989). A bootstrap method (Efron and Tibshirani, 1993) produces 100 statistical realizations of the population from which the original data were drawn by combining the tendency curve with randomly selected residuals from the curve according to month (Harris et al., 2001). The growth rate curve is obtained by numerical differentiation of the tendency curve with the $95 \%$ confidence limits determined using the standard deviation of the growth rate curves from the 100 bootstrap samples. The average ozone growth rate is a measure of the overall change.

\section{Results and discussion}

Changes in tropospheric ozone are presented for the N.H. and S.H. In the N.H. because of the greater availability of data and the heterogeneous character of the changes, individual consideration is given to various regions.

\subsection{Changes in the northern hemisphere}

Developing a picture of longer-term variations of ozone in the N.H. troposphere requires consideration of several significant factors including the influence of anthropogenic emissions of ozone precursors from densely populated regions in Europe, Asia, and North America. There are also differences between N.H. regions in the extent to which precursor emissions are regulated. The influence of the continents in the N.H. also leads to varying conditions such as those seen in warm conveyor belts (Cooper et al., 2004) that are effective in mixing precursors from the boundary layer into the free troposphere. It might be expected that under these conditions a good deal of heterogeneity should exist in the long-term behavior of tropospheric ozone among individual station locations. That this is indeed the case is illustrated in Fig. 1. These six sites cover a range of conditions that represent several regional patterns. The results for the N.H. are presented by considering changes at high and mid latitudes (including the subtropics-locations north of $25 \mathrm{~N}$ ) and the tropics where the station in Hawaii is the only available N.H. tropical station with a longer-term time series.

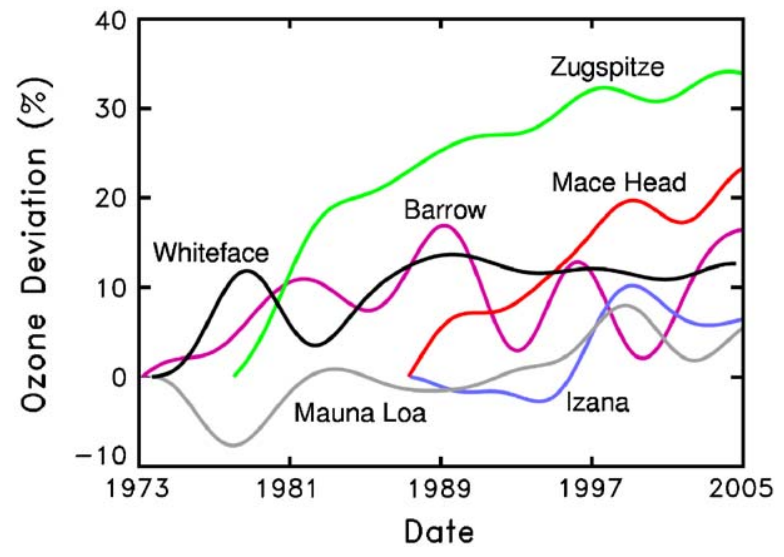

Fig. 1. Ozone trend curves (determined from the fit to the difference between the modeled data and the observations) in percent deviation at six selected N.H. surface ozone sites (Barrow - magenta, Mace Head - red, Zugspitze - green, Whiteface Mountain — black, Izana - blue, Mauna Loa-gray).

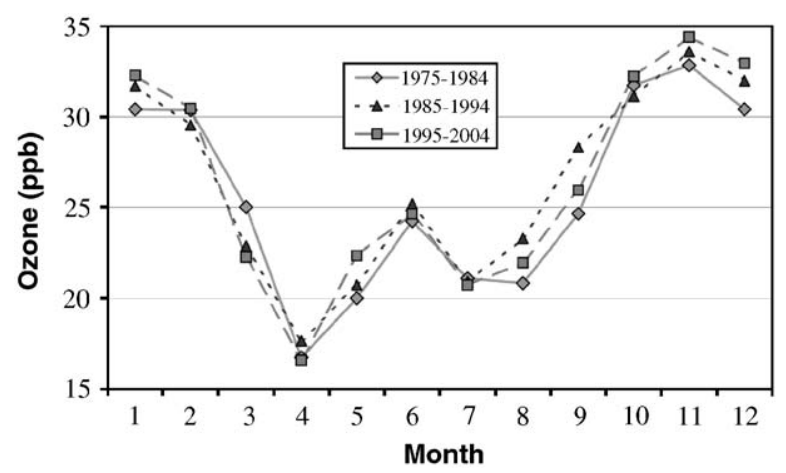

Fig. 2. Average monthly surface ozone at Barrow, Alaska, for three time periods.

\subsubsection{High latitudes}

At high latitudes of the N.H. the longest observational series are in the North American sector. Surface measurements at Barrow $(70 \mathrm{~N})$ since 1973 and Alert (82N) since 1992 are significantly influenced by boundary layer, springtime ozone depletion related to bromine chemistry (Barrie et al., 1988; Oltmans, 1991). Ozonesonde records at Resolute (75N) beginning in 1979 and Alert beginning in 1987 also show the signature of springtime depletion in the low-level observations but are unaffected above the boundary layer (Oltmans, 1993). The site at Denali National Park (64N) in the interior of Alaska is not influenced by the springtime depletion. The long record at Barrow shows a significant $4.8(1.7) \%$ /decade increase. The winter months of November-January and May 
(statistically significant individual monthly increases in December and May) are the primary contributors to the overall increase (Fig. 2). In the late summer months there was an increase from the early period (1973-1984) to the middle decade (Fig. 2). The early period was the time of the development of, and maximum in, petroleum extraction activities on the North Slope of Alaska that peaked in the late1980s. The Prudhoe Bay facility was a major source of $\mathrm{NO}_{x}$ emissions, equivalent to those of Washington, DC at the time (Jaffe, 1991). Surface ozone at Barrow also peaked at this time (Fig. 1) and though there have been fairly large interannual variations since then, there has been little overall change in the last 15 years (Fig. 1). During the most recent decade, August and September values have dropped back to near those of the early period (Fig. 2). This may reflect the decline in petroleum production in the recent decade.

The ozonesonde record at Resolute beginning in 1980 shows a very small overall decline. The record shows a significant decline during the first half of the record followed by an increase to levels near those at the beginning of the record (Fig. 3). This is a pattern seen at all the Canadian stations north of $50 \mathrm{~N}$ with records going back to 1980 (Churchill, Goose, Edmonton). At Alert both the ozonesonde record, which begins in December 1987, and the surface measurements that began in 1992 show significant increases. This period corresponds to the time of increasing tropospheric ozone at the longerterm Canadian ozonesonde stations. The increases

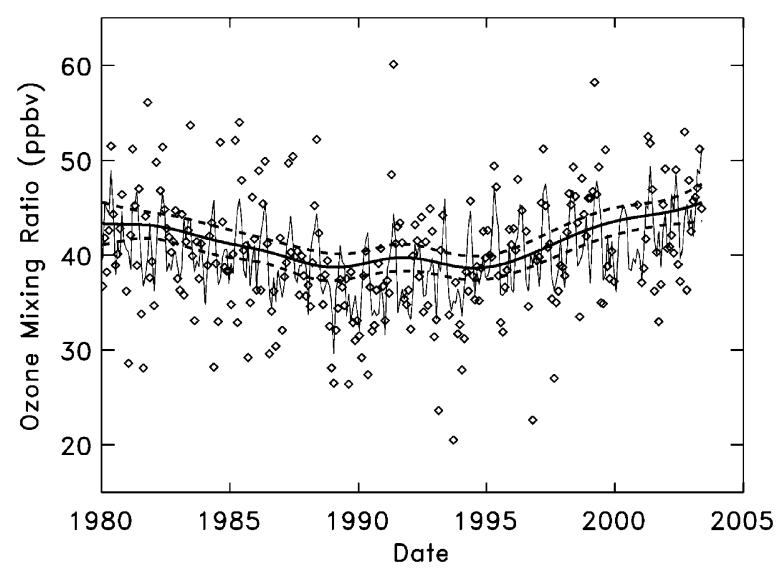

Fig. 3. Monthly average ozone amounts at Resolute in the 850-700 hPa layer (diamonds), the modeled values (gray solid line), and the fit (black solid curve) to the residuals (the difference between the data and the model) with the $95 \%$ confidence interval (black dashed curves). at Alert in both the surface and ozonesonde records occur during the winter and spring months with significant individual monthly trends in January, April, and June. The long-term change at the highlatitude Canadian ozonesonde stations has been shown to be strongly related to the wintertime frequency of occurrence of ozone lamina in the lowest part of the stratosphere (Tarasick et al., 2005). There is a strong correlation between the interannual variability of these lamina and ozone amount in the lower stratosphere as well as in the long-term pattern of change (Tarasick et al., 2005). The correlation between ozone changes in the lower stratosphere and in tropospheric ozone is also very significant leading to the conclusion that at least a portion of the changes in troposphere results from changes in the lower stratosphere (Tarasick et al., 2005). At Denali NP, where the period of surface measurements corresponds in length with the ozonesonde record at Alert, the pattern of change is remarkably similar with winter and spring increases in the most recent decade. This increase is also seen in the shorter Alert surface record (8.7 $( \pm 5.0) \%$ /decade $)$. In assessing the long-term changes in the Arctic it is important to be cognizant of the period being considered since there have been extended periods of both declining and increasing ozone amounts. The longest surface and ozonesonde records show varying patterns of change on multi-decadal time scales.

\subsubsection{Mid latitudes and subtropics}

4.1.2.1. Changes over Europe and the North Atlanti$c$. One of the largest changes in tropospheric ozone is seen at Zugspitze $(48 \mathrm{~N})$, a continental European location (Fig. 1), with an overall increase of 12.6 $( \pm 0.8) \% /$ decade. While ozone increased signifi-

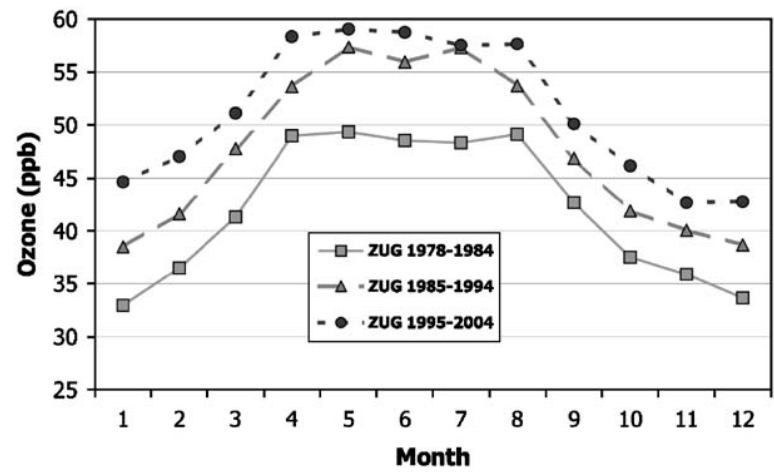

Fig. 4. Average monthly surface ozone at Zugspitze for two time periods. 
cantly during all months over the observational record, the largest increase was during the spring and summer months during the earliest portion of the record (Fig. 4). This is in contrast with the smaller summer increases during the most recent period (1995-2004) compared to the previous period (1985-1994). The change between the later two segments shows increases that are primarily in the autumn and winter. This pattern with both the strong increase during the warmer months in the early period and an increase in the cooler months during the later period suggests the influence of changing ozone precursor emissions on the ozone trend (Scheel, 2003). This results from less production in the summer and less titration by NO in the winter as $\mathrm{NO}$ emissions have declined over Europe (Lindskog et al., 2003; Lovblad et al., 2004; Jonson et al., 2005).

The ozonesonde record at Hohenpeissenberg (Claude et al., 2004), also located in southern Germany, extends back to 1966. The pattern of long-term change in the $700-500 \mathrm{hPa}$ layer (Fig. 5) shows many of the characteristics seen at Zugspitze (Fig. 1) with large increases in the early period (including the period from the mid-1960s to the mid-1970s) into the mid-1980s and smaller changes, even declines, thereafter. The small declines seen in the most recent decade at Hohenpeissenberg, although not seen at Zugspitze, have also been noted at the nearby Alpine site of Wank and result primarily from summer decreases (Scheel, 2003). The trends at the Zugspitze and Hohenpeissenberg

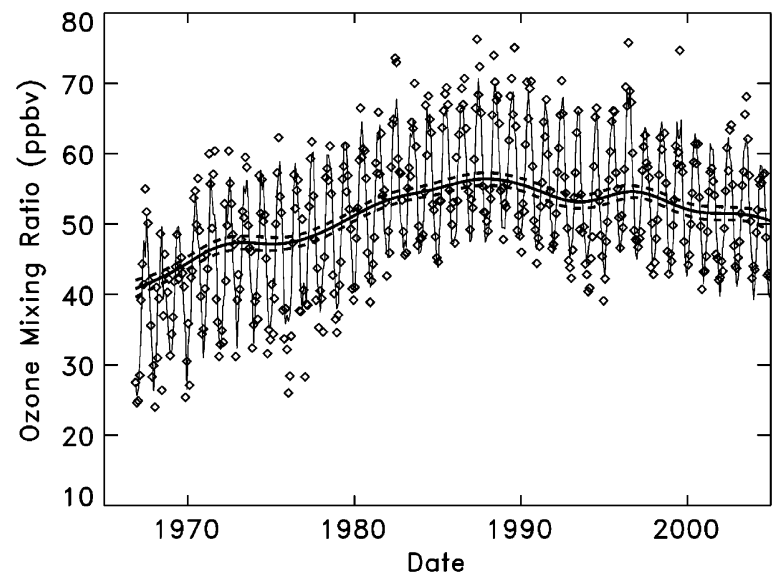

Fig. 5. Monthly average ozone amounts at Hohenpeissenberg in the 700-500 hPa layer (diamonds), the modeled values (gray solid line), and the fit (black solid curve) to the residuals (the difference between the data and the model) with the $95 \%$ confidence interval (black dashed curves). also follow a similar seasonal pattern (Figs. 4 and 6). The overall agreement between the surface measurements at the high-altitude Zugspitze site and the vertical profile measurements at Hohenpeissenberg lend confidence to these results and suggest that they are indicative of the pattern over continental western Europe.

Two stations in the eastern North Atlantic, Izaña and Mace Head, also show significantly increasing ozone amounts over their period of record, which begin in 1987 (Fig. 1). The high-altitude site at Izaña, Canary Islands $(26 \mathrm{~N})$, is influenced by flow from both the mid latitudes and the subtropics. While increases are seen in most months, the statistically significant changes are during winter and spring months (Fig. 7). At Mace Head, Ireland, there is a preponderance of flow from the north Atlantic sector, especially during the winter and spring months when increases are the largest.

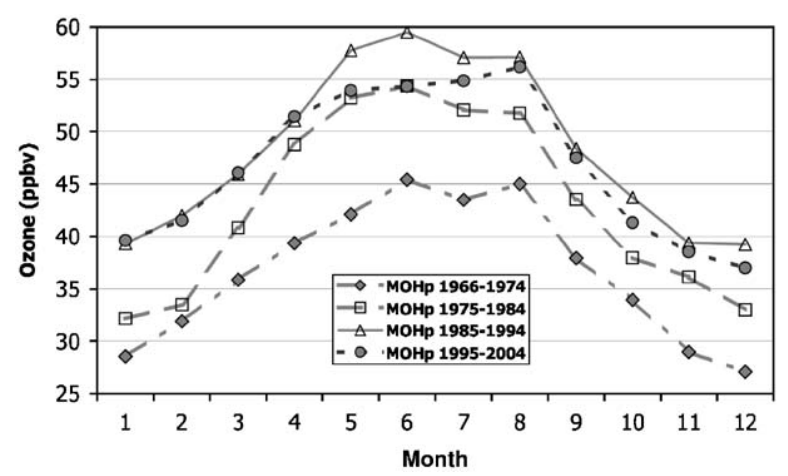

Fig. 6. Average monthly $850-700 \mathrm{hPa}$ layer average ozone at Hohenpeissenberg for three time periods.

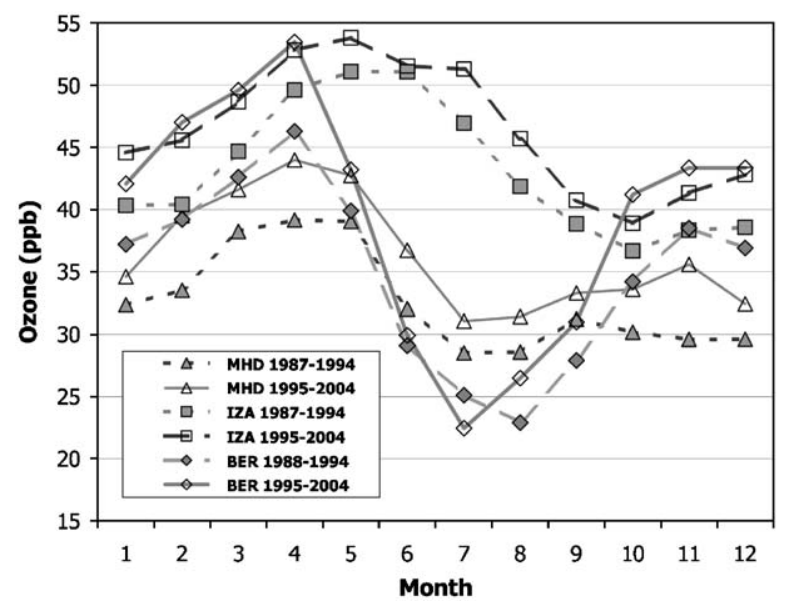

Fig. 7. Average monthly surface ozone for three sites in the North Atlantic for two time periods $(\mathrm{MHD}=$ Mace Head, $\mathrm{IZA}=$ Izana, BER = Bermuda). 
Simmonds et al. (2004) found that there was a significant increase in baseline ozone in clean oceanic air masses reaching Mace Head. On the other hand, declines were found in photochemically produced ozone in summertime, regionally polluted air masses. The mid Atlantic station in Bermuda (32N) began measurements in 1988 and operated until May 1998 and resumed measurements in 2003. Comparison of monthly average values prior to 1995 with those since, show higher amounts in the winter and spring months in the later period (Fig. 7). The significant data gap makes a rigorous statistical testing of this difference impractical, but Bermuda appears to fit the pattern of the other two North Atlantic sites. Lelieveld et al. (2004) presented results from a longer series of measurements in the Atlantic and found increases up to about $40 \mathrm{~N}$, but not further north.

4.1.2.2. Changes over Japan. In East Asia the primary source of information on longer-term tropospheric ozone changes are the ozonesonde records from three Japanese locations. The most complete record is at Tsukuba $(36 \mathrm{~N})$, which is located within $50 \mathrm{~km}$ of Tokyo. It can be expected that data in the lowest portion of the profile are strongly influenced by regional pollution (Logan et al., 1999; Oltmans et al., 2004). The long-term record at Tsukuba shows an overall increase through the troposphere (Fig. 8). This increase comes during the period into the late-1980s and encompasses most of the troposphere. The other

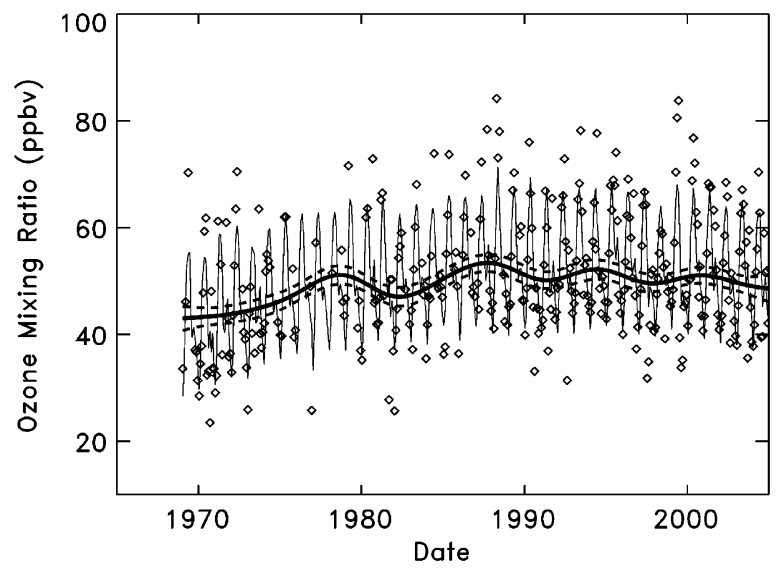

Fig. 8. Monthly average ozone amounts at Tsukuba in the 850-700 hPa layer (diamonds), the modeled values (gray solid line), and the fit (black solid curve) to the residuals (the difference between the data and the model) with the 95\% confidence interval (black dashed curves). two Japanese stations with long records, Sapporo $(40 \mathrm{~N})$ and Kagoshima (32N), show a similar overall pattern. Flow from regionally polluted air masses from China appears to be the major contributor to the long-term change at Tsukuba and Kagoshima (Naja and Akimoto, 2004). At Sapporo the change is associated with longer-range flow from the Eurasian continent at higher latitudes (Naja and Akimoto, 2004). Since the beginning of the 1990s, the overall trend has been weakly downward at all of the Japanese locations with perhaps somewhat stronger declines in the most recent years. It should be noted that during the late-1970s, there are very few observations and during the 1980s there are almost no soundings in the summer months. The subtropical site at Naha $(26 \mathrm{~N})$ began measurements
LAYER PRESSURE

$\begin{array}{ll}1 & \mathrm{SFC}-850 \mathrm{hPa} \\ 2 & 850-700 \mathrm{hPa} \\ 3 & 700-500 \mathrm{hPa} \\ 4 & 500-300 \mathrm{hPa}\end{array}$
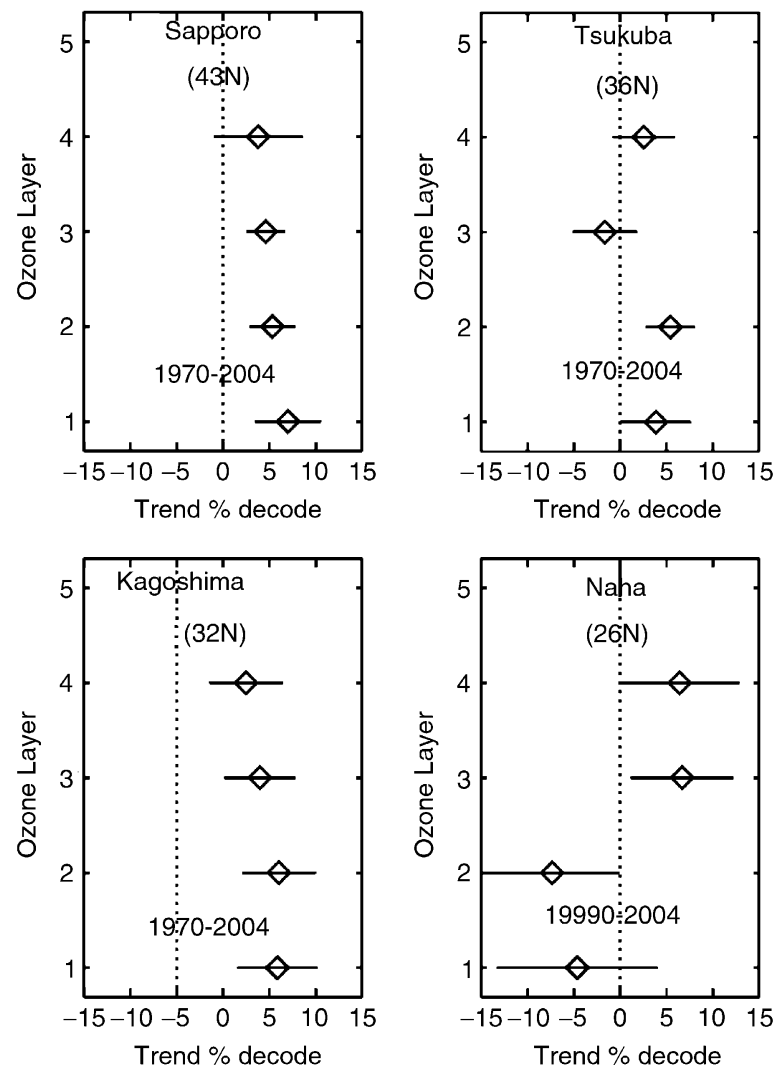

Fig. 9. Trend with altitude of the ozonesonde layer averages at four Japanese stations. Sapporo, Tsukuba and Kagoshima data are for the period 1970-2004 while Naha only includes the period 1990-2004. 
in 1989 and like the other Japanese stations during this period shows no significant change (Fig. 9). This lack of change comes in spite of the rapid industrialization in China and the documented rise in $\mathrm{NO}_{x}$ emissions in East Asia (Naja and Akimoto, 2004 and references therein; Richter et al., 2005). This lack of congruence between recent emission increases in East Asia and relatively flat ozone changes over Japan remains largely unexplained (Naja and Akimoto, 2004).

4.1.2.3. Changes over North America. Over the mid latitudes of North America, there are several longerterm records both at the surface and from ozonesondes. At more northerly mid latitudes the three Canadian ozonesonde stations at Churchill (59N), Edmonton (54N), and Goose (53N) have a pattern of change similar to that described earlier for the high Arctic station at Resolute with a correspondingly similar, though a bit weaker, relationship between lower stratospheric phenomena and tropospheric ozone change (Tarasick et al., 2005). The result is that after a period of decline followed by an increase, the overall trend is small in the troposphere for these locations (Fig. 10).

The longest tropospheric ozone time series in North America is the ozonesonde record at Wallops Island, Virginia, that begins in 1970 (Fig. 11). The primary feature of this record is the anomalously high values in the late-1980s centered on 1988 with relatively small changes during other periods. This is in contrast to the pattern seen over continental Europe and Japan (Fig. 11). Overall the change is rather small at all tropospheric altitudes. There has been a slight tendency for summer months to decline and winter months to increase. The longest continuous surface record in the US is at Whiteface Mountain, New York (Fig. 1). This site is impacted by regional pollution but is not located in close proximity to an urban area. It is also at an elevated altitude $(1480 \mathrm{~m})$ and can be considered representative of a broader scale regional pattern. There have been significant declines during May and August and increases during December and January. These changes have not been dramatic, but represent a shift away from the highest values during the warmer months when the seasonal maximum occurs and from lower values during the winter months at the time of the seasonal minimum (Fig. 12). This appears to be in keeping with the pattern seen for reductions in $\mathrm{NO}_{x}$ (Jonson et al., 2005) and similar to that seen in the profile measurements at Wallops Island.
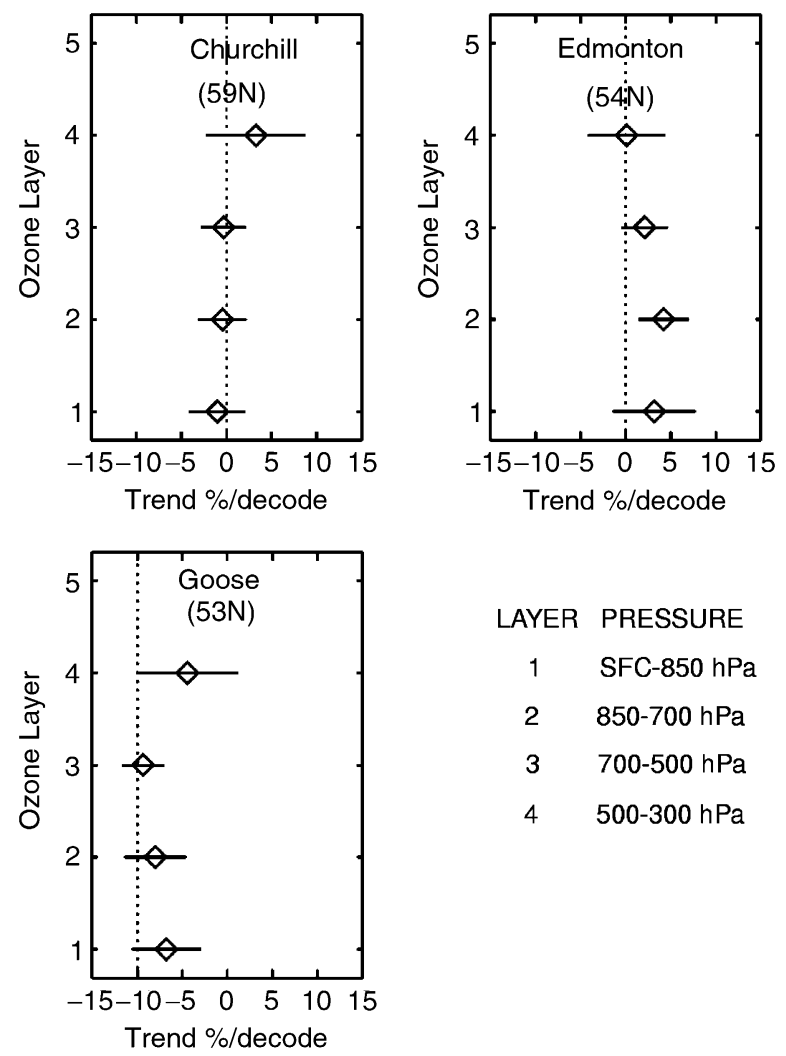

\section{LAYER PRESSURE \\ 1 SFC-850 hPa \\ $2 \quad 850-700 \mathrm{hPa}$ \\ $3 \quad 700-500 \mathrm{hPa}$ \\ $4 \quad 500-300 \mathrm{hPa}$}

Fig. 10. Trend with altitude of the ozonesonde layer averages at three Canadian stations for the period 1980-2004

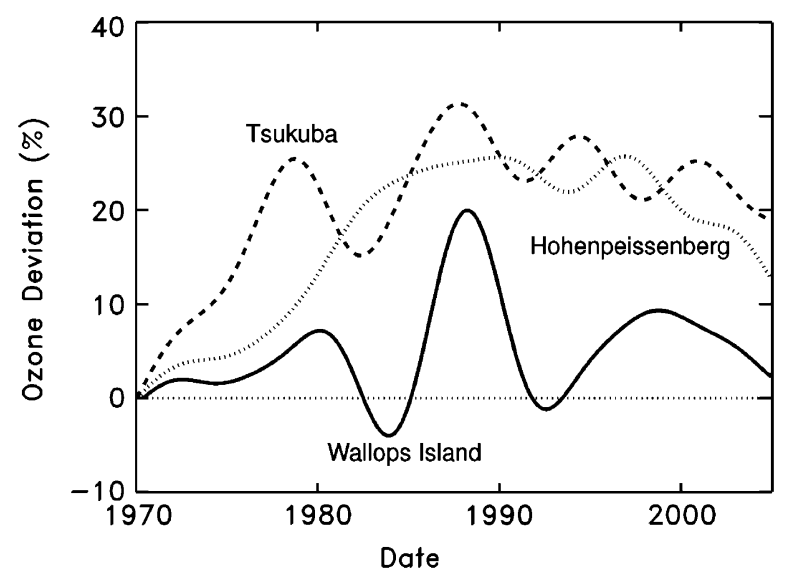

Fig. 11. Ozone trend curves (determined from the fit to the difference between the modeled data and the observations) in percent deviation for Hohenpeissenberg, Tsukuba, and Wallops Island for the $850-700 \mathrm{hPa}$ layer.

Several National Park sites in the western US have surface ozone measurements starting in the mid- to late-1980s. These sites (Yellowstone, 


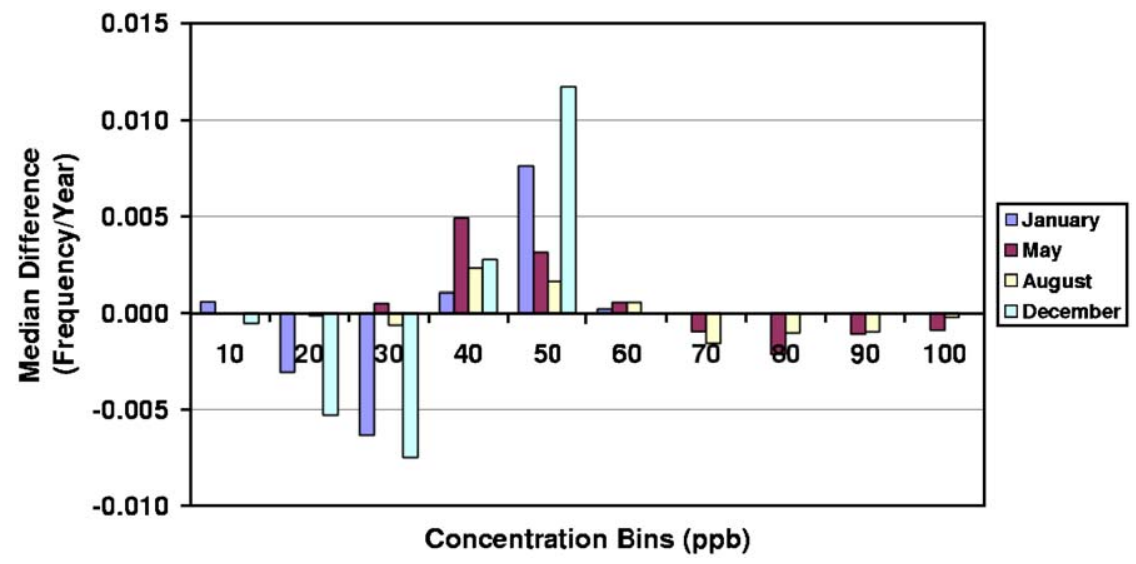

Fig. 12. The distribution of changes in surface ozone concentrations at Whiteface Mountain, New York, by month for months with significant changes in the distribution. The mass in the histogram for each month sums to one. The changes (pluses and minuses) add approximately to zero. A change in the frequency per year can be translated into hours by multiplying the plotted number by the total number of hours in the month. For example a month with $720 \mathrm{~h}$ and a frequency of 0.01 per year represents a shift from one concentration bin to another of $7 \mathrm{~h}$ per year. The median difference is computed by differencing between individual years (for example 1982-1983, 1982-1984, 1982-1985, ..., 1983-1984, 1983-1985, 1983-1986, ...). The plotted value is the median of these differences for each month and each concentration bin with a significant change.

Wyoming; Glacier, Montana; and Olympic, Washington) are generally remote from significant urban and most regional pollution influences. For the approximately 15 -year data records at each site, only Olympic shows a single month (February increase) with a significant change indicating that for these more remote sites there have not been important recent changes, related to either local or distant sources. At the ozonesonde site at Boulder, Colorado, scattered profile measurements began in 1979 and a regular sounding program started in 1985. The longer record shows modest declines overall while the more robust record beginning in 1985 also shows a small decline through the troposphere that took place almost exclusively in the earliest portion of the record.

Two contrasting sites in northern California point out the difference in change recorded at locations that are not separated geographically by a large distance. The Lassen Volcanic National Park record, which has been described by Jaffe et al. (2003), shows marked increases during the warm months (April-August) for the period 1988-2003. On the other hand, the site at Yreka, near the northern border of California, shows no overall change for 1981-2003 with small increases in September and decreases in January. It has been suggested that the spring increases seen at Lassen may be the result of trans-Pacific transport of enhanced ozone from Asia emissions (Jaffe et al.,
2003). The Yreka record suggests that longer-range effects may not be playing a major role, however, since no spring increases are noted. Lassen is located downwind of the rapidly expanding northern portion of the central valley of California where there are numerous air quality violations in locations in the vicinity of cities such as Redding. The spring increases at Lassen could result from the more immediate upwind population centers that would also contribute to the summer rise.

\subsubsection{Tropics}

The only long-term record of tropospheric ozone at lower latitudes of the N.H. is from Hawaii in the Pacific Ocean. The continuous monitoring site at the $3400 \mathrm{~m}$ altitude Mauna Loa Observatory (MLO) began measurements in 1973 (Fig. 1). Ozonesonde observations from Hilo $(20 \mathrm{~N})$ began in 1982. The Hawaiian location sees transport events that may have their origin in East Asia. These events occur most frequently in the spring and are occasionally accompanied by higher ozone amounts (Oltmans et al., 2004). Transport from continental regions and higher latitudes brings higher ozone amounts to Hawaii than air masses that remain over the ocean for extended periods of time or come from lower latitudes (Harris et al., 1998). However, the long-term increase in Hawaii $(3.5 \pm 1.5 \% /$ decade $)$ has occurred during the autumn and winter, which is the seasonal minimum in 
tropospheric ozone, with the largest changes coming in September and October (Fig. 13). In September and October the distribution of the hourly values has changed dramatically with occurrences in the $20-30 \mathrm{ppb}$ range declining while hourly values in the $40-50$ and $50-60 \mathrm{ppb}$ have increased significantly (Fig. 14). This shift has occurred primarily in the most recent decade (Fig. 13) and is corroborated in the ozonesonde record (Fig. 13) that shows that this change extends through the mid troposphere $(850-500 \mathrm{hPa})$. The similar behavior of the independent continuous monitoring data at MLO and the weekly profile data from Hilo indicates that this is a very robust result.

It is likely that the change in the autumn months is associated with a shift in transport characteristics of air masses reaching the island of Hawaii. Back trajectories to MLO computed for the 10-year

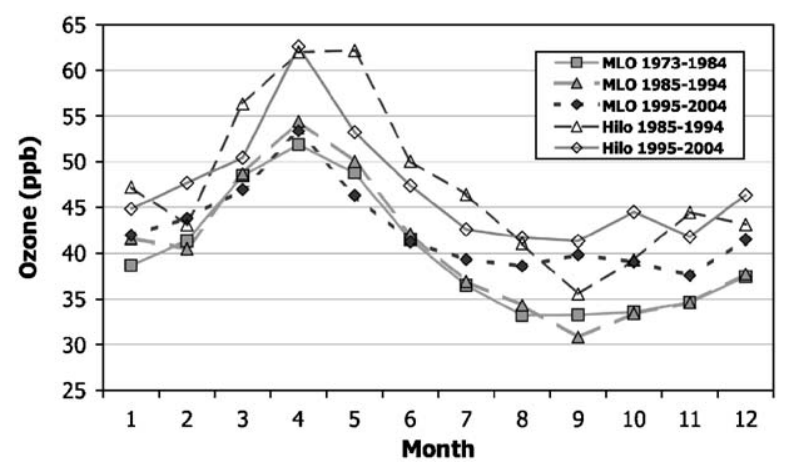

Fig. 13. Seasonal variation in surface ozone (filled symbols) at Mauna Loa Observatory (MLO) and in the 700-500 hPa layer ozone (open symbols) at Hilo, Hawaii, for different 10-year time periods. periods 1985-1994 and 1995-2004 (Fig. 15) show that in the earlier period $13 \%$ of the 10 -day back trajectories fall in a cluster (Moody, 1986; Harris and Kahl, 1990) whose mean trajectory originated north of $30 \mathrm{~N}$, while in the most recent period $42 \%$
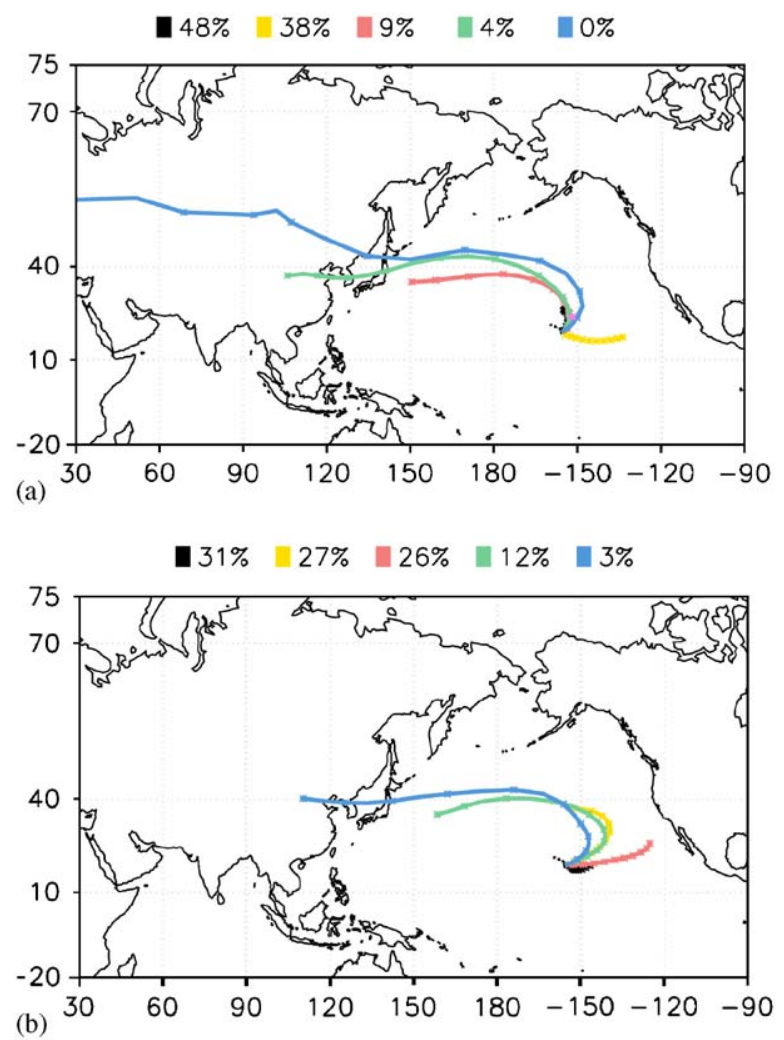

Fig. 15. Clustered trajectories for Mauna Loa Observatory for the months of September and October for the (a) 1986-1994 and (b) 1995-2004 time periods.

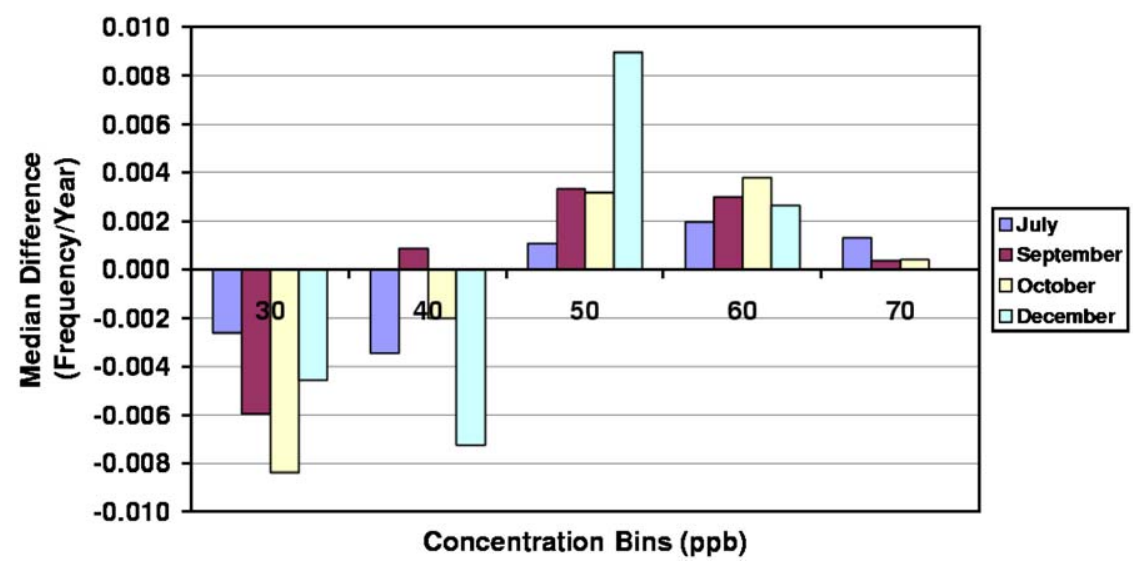

Fig. 14. The monthly change in the distribution of hourly average concentrations of Mauna Loa surface ozone expressed as the median difference of occurrence of hourly averages in each concentration bin for each month with a significant change. 
fall in a cluster whose mean originated north of $30 \mathrm{~N}$. Given the latitudinal gradient with higher ozone amounts to the north of Hawaii (Logan, 1999; Oltmans et al., 2004), this change in the transport is likely the primary factor in producing the shift to higher ozone amounts in the autumn months.

The MLO observations for the month of May show a noticeable decline (though not significant at the $95 \%$ confidence level) between the most recent decade and earlier 10-year intervals (Fig. 13). This difference is even more noticeable in the ozonesonde data (Fig. 13) and has a large vertical extent $(850-300 \mathrm{hPa})$ that includes much of the troposphere. Even though this is still a month of significant transport from Asia, this change is not likely related to changing precursor emissions, which have increased over this time (Naja and Akimoto, 2004). As with the autumn change, it appears that the May decline is a result of a shift in transport characteristics. Clustered back trajectories for the pre- and post-1994 periods for the month of May demonstrate a decline in the most rapid flow from the west that extends back to Asia and they declined from about $34 \%$ of trajectories in the earlier period to only $20 \%$ in the most recent period. Flow from the east that seldom reaches a continent in 10 days increased from $30 \%$ of all cases to $50 \%$ of the trajectories. A decline in the number of trajectories with a significant westerly component will generally mean reduced ozone amounts at Hawaii (Oltmans et al., 1996).

\subsection{Ozone changes in the southern hemisphere}

Because the S.H. has much smaller land area and lower population than the N.H., it might be expected that human activity plays a smaller role in tropospheric ozone changes in the S.H. On the other hand, extensive biomass burning, particularly in Africa and South America during the austral winter and spring, is unique to the S.H. This burning in the absence of other strong anthropogenic inputs should play a significant role in overall tropospheric ozone levels in the S.H. and should influence the seasonal pattern as well. The difference in the level of anthropogenic influence between the S.H. and N.H. is reflected in the gradient between the hemispheres in carbon monoxide (Novelli et al., 2003) and likely in ozone as well (Fabian and Pruchniewicz, 1977; Fishman and Seiler, 1983; Winkler, 1988; Oltmans and Levy II, 1994).

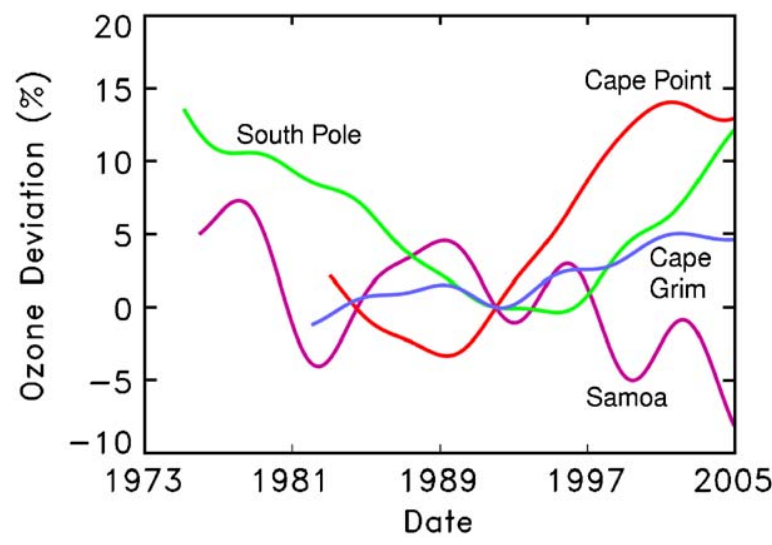

Fig. 16. Ozone trend curves (determined from the fit to the difference between the modeled data and the observations) in percent deviation at four selected S.H. surface ozone sites (South Pole-green, Cape Grim-blue, Cape Point—red, Samoamagenta).

Significant surface ozone changes have occurred on decadal time scales at background S.H. sites (Fig. 16). At the South Pole, surface ozone amounts declined through the 1980s into the early 1990s with a recovery in the most recent decade. At the mid latitude sites at Cape Grim, Australia and Cape Point, South Africa, ozone amounts have increased since the early 1990s with the increase at Cape Point being the largest. At Samoa there have been large multi-year variations and an overall decline.

Consideration of the seasonal cycle at these locations, as well as at the coastal Antarctic site at Arrival Heights (with a shorter record than the other sites), provides some insight into the longerterm changes and their relationship to each other. The mid latitude site at Cape Grim serves as something of an anchor point for comparison purposes for changes at the locations to the north and south. The time series at this site has benefited from the use of simultaneous measurements from two well-calibrated UV ozone monitors throughout the entire record (Meyer et al., 1990).

Fig. 17 shows the time series at five S.H. stations for a 4-year period from 2000 to 2003. This figure illustrates the relationship between the low latitude, low altitude site at Samoa (with correspondingly low ozone amount) to the high-latitude, highaltitude South Pole location. Apparent is the near synchronization of the seasonal cycle at all latitudes with high ozone in the austral winter and strong draw down in the summer (Ayers et al., 1992). All of the non-tropical sites show similar minimum values with the exception of South Pole, which has a 


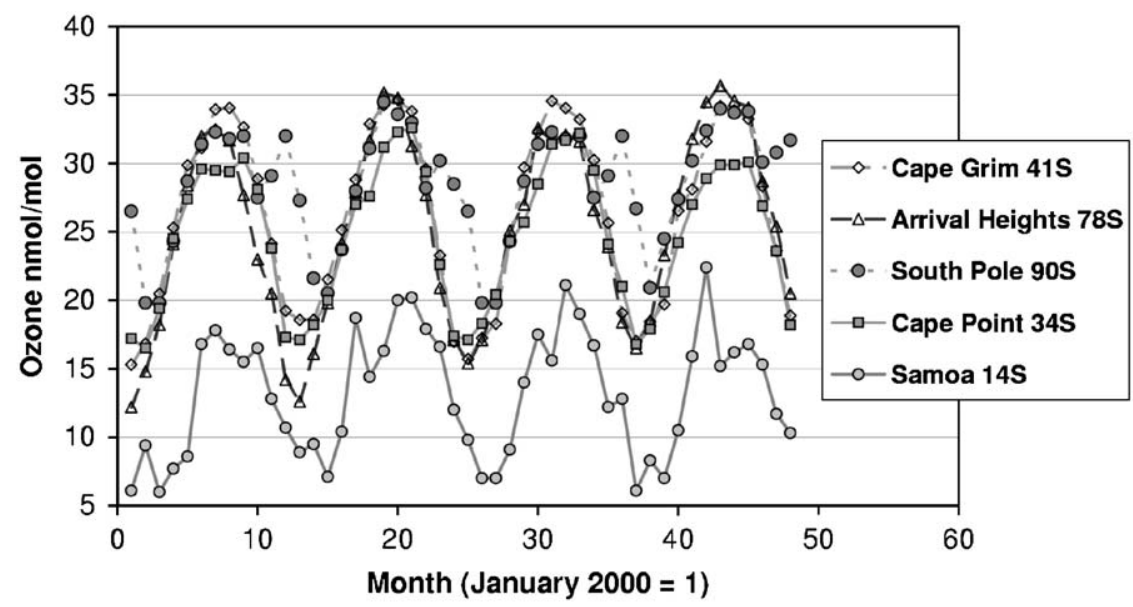

Fig. 17. Time series of monthly mean surface ozone at five sites in the S.H. for the period 2000-2003.

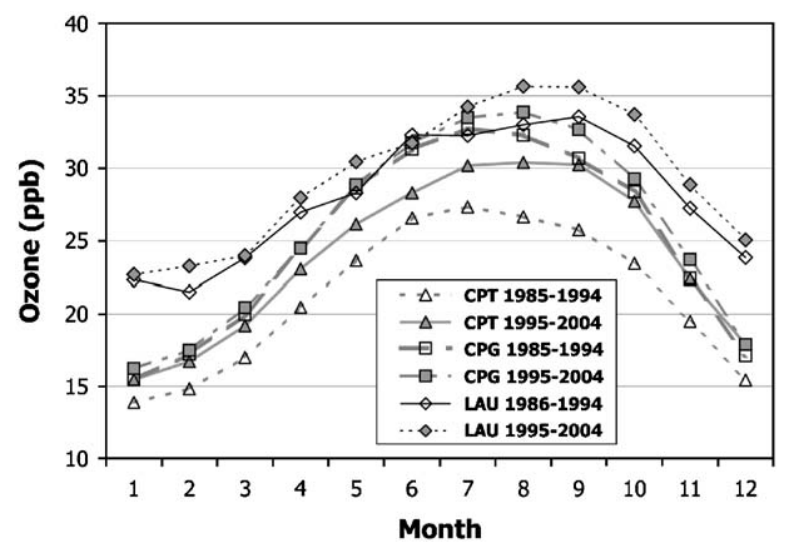

Fig. 18. Average seasonal cycle of surface ozone at Cape Point (CPT) and Cape Grim (CPG) and the 850-700 hPa layer average ozone at Lauder (LAU) for two time periods.

secondary peak in the austral summer so that the minimum never dips down to the lower values seen at Cape Point, Cape Grim, and Arrival Heights. The coastal Antarctic site at Arrival Heights is more similar to Cape Grim than to the inland Antarctic South Pole location. To get a picture of the change in the seasonal pattern with time, the data are divided into two time periods with the break between 1994 and 1995. In addition at South Pole and Samoa, where data are available from 1975, the period 1975-1984 is considered.

At Cape Point and Cape Grim there are clear differences between the two time periods and the two sites (Fig. 18). At Cape Grim there has been essentially no change during the summer seasonal minimum, but a significant increase during the late winter and early spring. There has been some increase throughout the year at Cape Point, but the largest increase is again in the late winter and spring. In the later period the Cape Point values have risen nearer to those seen at Cape Grim. The large change seen at Cape Point is very consistent with results from shipboard measurements in the eastern South Atlantic (Lelieveld et al., 2004) that cover the same period as the Cape Point observations. These changes were the largest of any of the latitude bands surveyed.

The seasonal increase at Cape Grim occurs during a time of the year when biomass burning in the S.H. is very active. However, trends in this activity on a decadal time scale have not been reported. It might also be expected that if burning were driving the ozone changes at Cape Grim and Cape Point, this would be reflected in long-term changes in carbon monoxide. Both of these sites have $\mathrm{CO}$ records similar in length to the surface ozone measurements, but neither of these sites has seen a long-term increase in CO (Langenfelds et al., 2003; Brunke et al., 1995). The absence of an increase in $\mathrm{CO}$ at these sites is reflected in the results from hemisphere-wide measurements as well (Novelli et al., 2003). A preliminary analysis of back trajectories to Cape Point during the two different time periods does not reveal a significant shift in the transport patterns. Since Cape Grim represents the highest amounts in the hemispheric gradient (Fig. 17), changes in horizontal transport cannot explain the increase at Cape Grim. Because the amount of ozone in the troposphere generally increases with altitude, changes in air mixed down from above could play a role in the change seen at the surface. The ozone profile record at Lauder, 


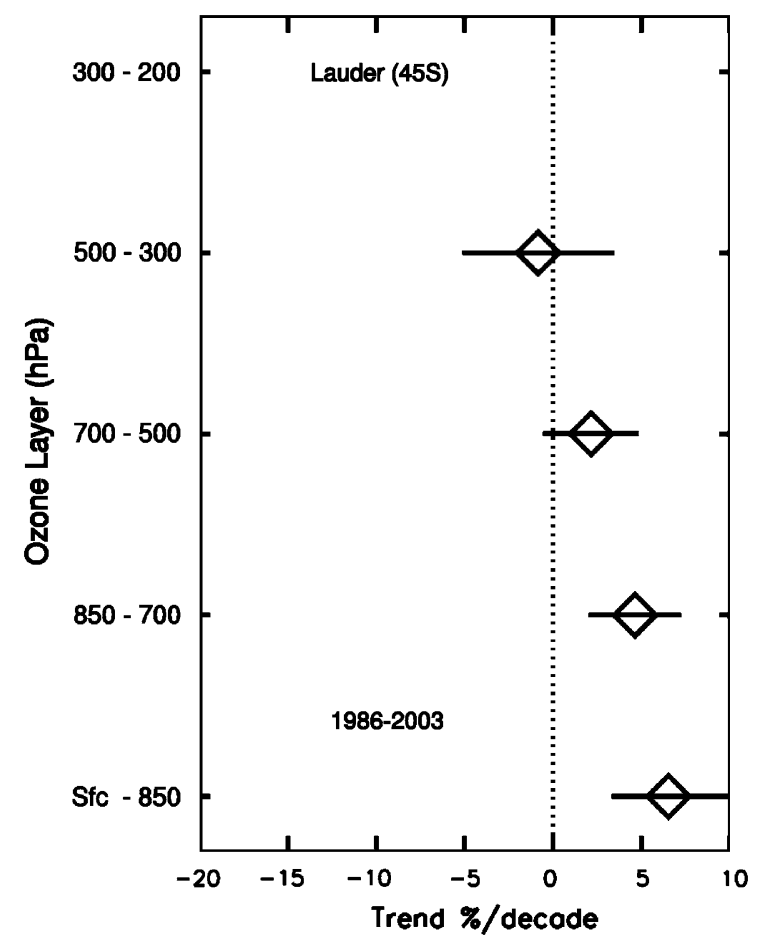

Fig. 19. Trend in altitude layers from ozonesonde data at Lauder, New Zealand.

New Zealand (45S), from ozonesondes also shows increases in the middle and lower troposphere (Fig. 19). The changes in the free troposphere at Lauder also follow the seasonal pattern seen at the surface sites with the largest increases during the spring (Fig. 18). This record does not, however, show a long-term change in the upper troposphere that could be indicative of enhanced fluxes from the stratosphere. Both the records at Cape Point and at Cape Grim indicate that there may have been a leveling off of the increases in the most recent years.

The seasonal pattern at Samoa (Fig. 20) shows no change in the seasonal maximum between the early period (1975-1984) and the 1985-1994 period and only small changes at other times of the year. The primary change from the earlier to the latest period is in the seasonal maximum (July-August). While there is a relatively complete ozonesonde record in the most recent decade at Samoa, ozonesondes were only flown between 1986 and 1990 in the previous decade. The representativeness of the record in this earlier period needs to be kept in mind, but the pattern seen in the surface data is reproduced in the ozonesondes (Fig. 20). This pattern is seen into the mid troposphere but not at higher altitudes.

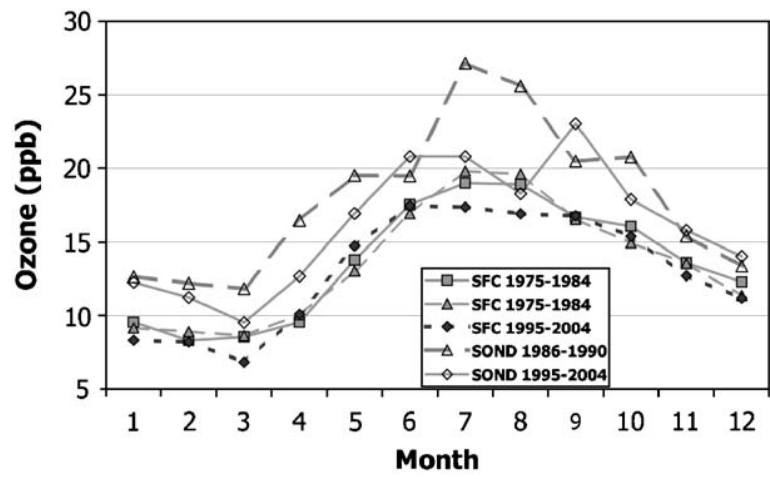

Fig. 20. Trend in altitude layers from ozonesonde data at Lauder, New Zealand.

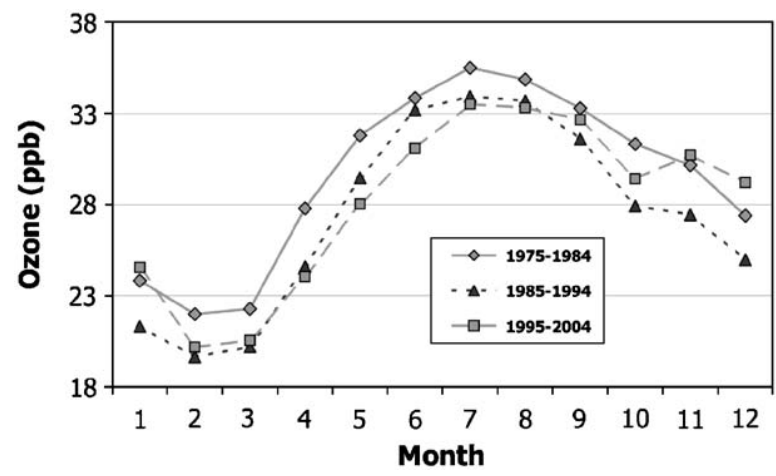

Fig. 21. Average monthly surface ozone at South Pole for three time periods.

As with other locations in the S.H., there has not been a long-term increase in $\mathrm{CO}$ (Novelli et al., 2003) in the S.H. tropical belt. During the seasonal maximum at Samoa, a greater proportion of transport is from higher latitudes and higher altitudes than during the time of the seasonal minimum (Harris and Oltmans, 1997); however, trajectories do indicate that a shift in transport to Samoa during July-August has occurred.

In Antarctica the South Pole station represents a unique environment in the S.H. located at high altitude on the extensive Antarctic plateau. The observational record with long periods of both declining and increasing amounts (Fig. 16) is a somewhat anomalous pattern compared with the other S.H. records and coastal Antarctic locations (Fig. 17). Although the overall trend at South Pole during the most recent period is increasing, all months from March to August for the most recent period (Fig. 21) have lesser amounts than the two earlier periods (1975-1984, 1985-1994). Although these changes are fairly small, they are statistically 


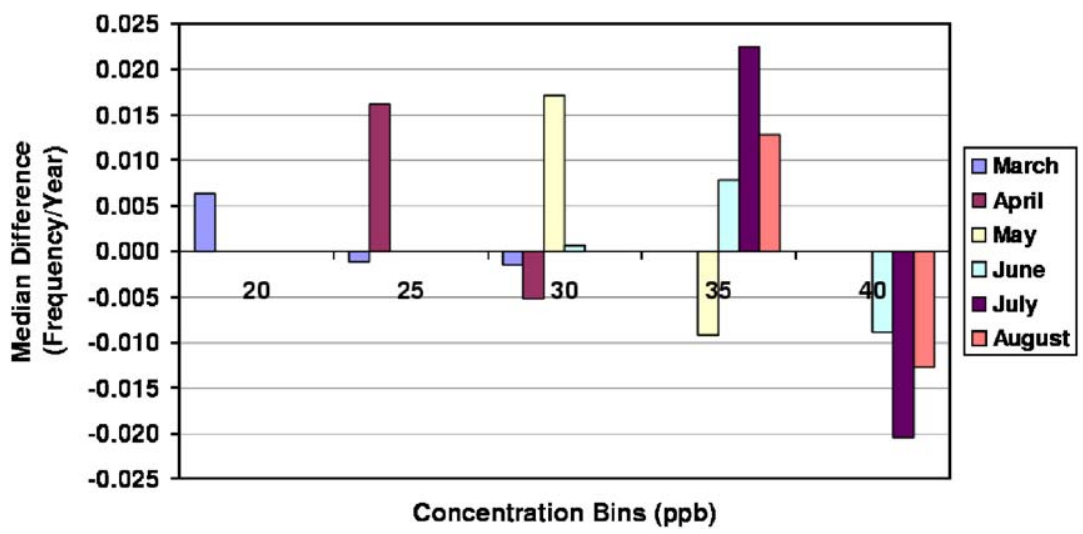

Fig. 22. The monthly change in the distribution of hourly average concentrations of South Pole surface ozone expressed as the median difference of occurrence of hourly averages in each concentration bin for each month with a significant change.

significant and represent a shift in the distribution (Fig. 22) during these months, indicating that larger values are getting smaller rather than low values getting even lower. Significant fluctuations at South Pole between the time periods take place in the late spring and summer (November-February). It is this season that appears to be contributing to the increasing ozone amounts seen in the overall trend (Fig. 16) during the latter period since other months have continued to decline in the most recent period. At Syowa (69S) there is very little change in the long-term ozonesonde record. Although the Syowa record began in 1966, the measurement series is very sparse during most years up to the 1980s. Comparing the record at Syowa over the same period, during which South Pole ozonesondes have been flown (1986-2004), reveals that the Syowa record does not have the tendency for higher values during the summer months in the most recent decade. This indicates that the processes controlling the summertime ozone behavior at these two sites are different. The unique behavior at South Pole is tied to ozone production in a very shallow layer $(<500 \mathrm{~m}$ in thickness) over the Antarctic plateau (Helmig et al., 2004) resulting from nitric oxide liberated photochemically from nitrate deposited in the snow surface (Crawford et al., 2001). During the period of strongly declining surface ozone amounts ( 1985-1994), the November-February period had uniformly lower ozone amounts than the earlier and later periods.

\section{Conclusions}

The picture of long-term tropospheric ozone changes is a varied one in terms of both the sign and magnitude of trends and in the possible causes for the changes. In several geographical regions the changes in time are broadly consistent with the expected behavior from changes in precursor emissions. In Hawaii a strong link to decadal variability in transport patterns could be identified. Especially for the most recent 10-15-year period, there are a number of locations such as the ozonesonde stations in Japan and Hohenpeissenberg, and both surface and ozonesonde sites in the US, where ozone has remained relatively unchanged or declined compared to earlier periods.

At high latitudes of the S.H. the surface and ozonesonde data at South Pole, which are in very good agreement with each other, indicate that some of the decadal scale changes seen in the surface record are related to the changing pattern of photochemical ozone production in the summer due to strong NO emissions from the surface snow layer (Crawford et al., 2001). This behavior is confined to a thin layer and it is not clear to what extent this phenomenon influences the broader Antarctic region.

At mid latitudes of the S.H. three time series of moderate length ( $\sim 20$ years) agree in showing increases that are strongest in the austral spring (August-October). Cape Point, South Africa (32S), shows the largest change. This is in keeping with the results of Lelieveld et al. (2004) that found the largest increases from shipboard measurements in the eastern Atlantic in the 20-40S latitude band. The agreement in the magnitude of the change is also good (3.6\%/decade for the shipboard data and $4.9 \% /$ decade at Cape Point) considering that the ship data are over a wide latitude band. The magnitude of the change in the ozonesonde record 
at Lauder, New Zealand (45S), falls between that seen at Cape Point and at Cape Grim, Australia (40S). The profile measurements at Lauder show this increase extending through the mid troposphere but not into the highest levels of the troposphere. The lack of a trend in the $\mathrm{CO}$ record in the S.H. makes a link to changes in biomass burning less likely. At Cape Point, where the change is largest, there is also no clear link to changing transport patterns.

At Samoa (14S), a tropical Pacific location, the most recent decade shows declines during July and August in the surface observations relative to the previous two decades. These changes are corroborated in the ozonesondes though the ozonesonde record prior to 1995 only encompasses a portion of the earlier decade (1986-1990). As at Cape Point and Cape Grim, neither the $\mathrm{CO}$ record nor changes in transport as determined from trajectory analysis provide ready clues as to the cause for this decline.

In the N.H. in the Arctic, a period of declining ozone in the troposphere through the 1980s into the mid-1990s has reversed and the overall change is small. Sites with shorter records mostly reflect the period of recovering ozone and hence show some increase that may not reflect the longer-term pattern. The decadal-scale variations in the troposphere in this region have been related, at least in part, to changes in the lowermost stratosphere by Tarasick et al. (2005).

At mid latitudes in the N.H., continental Europe and Japan showed significant increases in the 1970s and 1980s that appear to have leveled off or in some cases declined in the more recent decades. Over North America increases in the 1970s, as reflected in the Wallops Island ozonesondes and Whiteface Mountain surface data are less, suggesting significant regional differences. Time series, beginning in the 1980s at sites located in the mid latitudes of North America, generally confirm the modest changes in the most recent two decades. However, even at stations in relatively close proximity to each other, such as those in southern Germany, some differences in detail are seen. There is strong confirmation of the increase in the 1970s with a slowdown at both German sites thereafter. The high-altitude mountain site at Zugspitze suggests continuing smaller increases in recent decades while the ozonesondes at Hohenpeissenberg show declines through the troposphere. The variation in ozone trends over Europe and their relationship to precursor emissions is also seen in modeling studies
(Jonson et al., 2005) and observations (Schuepbach et al., 2001). In particular, changes over Europe cannot be fully explained based on precursor changes alone (Jonson et al., 2005). Over the North Atlantic three widely separated sites show significant increases since the late-1990s that may have peaked in recent years. The source of these changes is not considered here, but are discussed in Simmonds et al. (2004). The results at mid latitudes can be compared to a recent model study of the evolution of tropospheric ozone in the twentieth century (Lamarque et al., 2005). The earliest time series considered here, beginning in the $1970 \mathrm{~s}$, are included in the most recent two decades (1970-1990) in the modeling study. The increases seen in the model over Europe and Japan are seen in the observations. Over eastern North America the three plus decade observational record considered here does not show much overall change. However, when considering the shorter overlapping time period studied in the model, both Wallops Island ozonesondes and the Whiteface Mountain surface record show significant increases primarily because of low values through the mid-1970s and relatively high ozone amounts in the late-1980s. The increase seen by the model in the 1970-1990 period is a result of increases in precursor emissions (Lamarque et al., 2005). The subsequent period of a leveling off and declines seen in the observational record beginning in the 1990s in all three regions is not considered in the modeling work. The changes in tropospheric ozone seen in the observations in the most recent 30-40-year period over Europe can also be viewed in the context of the observations extending further back in time (Staehelin et al., 1994). The large increases in ozone over Europe that are captured in the long records at Hohenpeissenberg and the Zugspitze appear to have begun in the 1950s with much more gradual changes prior to the $1950 \mathrm{~s}$ (Staehelin et al., 1994).

In the N.H. tropics the only long record is from Hawaii $(20 N)$. In both the surface record at the high-altitude MLO and the ozonesondes at Hilo there has been a significant increase in the autumn months in the most recent decade compared to earlier periods that drives the overall increase seen in the $30+$ year record at Mauna Loa. This appears to be related to a shift in the transport pattern during this season with more frequent flow from higher latitudes in the latest decade.

Although still not numerous, an increasing number of ozone monitoring sites and the lengthen- 
ing of a number of time series resulting from continuing observations should provide additional insight on tropospheric ozone changes over the next decade. In addition, the improved capability of models to simulate long-term tropospheric ozone behavior will make it beneficial to carry out a study such as that by Lamarque et al. (2005) that includes the most recent time period. It appears from the records considered here that there has been a leveling off of recent increases in the tropospheric ozone burden, particularly at mid latitudes of the N.H. that have been most affected by anthropogenic changes.

\section{Acknowledgments}

A large number of people have been responsible for the measurements at the sites used in this study. Their careful work is gratefully acknowledged. The work of Gerry Spain at the Mace Head Station, Alan Yoshinaga and Darryl Kuniyuki at the Mauna Loa Observatory, and Dan Endres at the Barrow Observatory is specifically acknowledged.

\section{References}

Ayers, G.P., Penkett, S.A., Gillett, R.W., Bandy, B., Galbally, I.E., Meyer, C.P., Elsworth, C.M., Bentley, S.T., Forgan, B.W., 1992. Evidence for photochemical control of ozone concentrations in unpolluted marine air. Nature 360, 446-449.

Barrie, L.A., Bottenheim, J.W., Schnell, R.C., Crutzen, P.J., Rasmussen, R.A., 1988. Ozone destruction and photochemical reactions at polar sunrise in the lower Arctic atmosphere. Nature 334, 138-141.

Brewer, A.W., Milford, J.R., 1960. The Oxford-Kew ozone sonde. Proceedings of the Royal Society, Series A 256, 470-495.

Bruhl, C., Crutzen, P.J., 1989. On the disproportionate role of tropospheric ozone as a filter against UV-B radiation. Geophysical Research Letters 16 (7), 703-706.

Brunke, E.-G., Scheel, H.E., 1995. The new Cape Point Baseline Station and recent changes in trace gas trends. In: Extended Abstracts of Papers Presented at the WMO-IGAC Conference on the Measurement and Assessment of Atmospheric Composition Change, Report 107, World Meteorological Organization, Geneva, pp. 246-249.

Claude, H., Hartmannsgruber, R., Köhler, U., 1987. Measurement of atmospheric ozone profiles using the Brewer/Mast sonde, WMO Global Ozone Research and Monitoring Project Report No. 17, WMO/TD No. 179.

Claude, H., Kohler, U., Steinbrecht, W., 2004. Evolution of ozone and temperature trends at Hohenpeissenberg (Germany) in OZONE. In: Zerefos, C. (Ed.), Proceedings of the XX Quadrennial Ozone Symposium, 1-8 June 2004, Kos, Greece, vol. I, Athens, pp. 314-315.
Cooper, O.R., et al., 2004. A case study of trans-Pacific warm conveyor belt transport: The influence of merging air streams on trace gas import to North America. Journal of Geophysical Research 109, 4393.

Crawford, J.H., et al., 2001. Evidence for photochemical production of ozone at the South Pole surface. Geophysical Research Letters 28 (19), 3641-3644.

Efron, B., Tibshirani, R.J., 1993. An Introduction to the Bootstrap. Chapman and Hall, New York (436pp.).

Fabian, P., Pruchniewicz, P.G., 1977. Meridonal distribution of ozone in the troposphere and its seasonal variation. Journal of Geophysical Research 82 (15), 2063-2073.

Fishman, J., Seiler, W., 1983. Correlative nature of ozone and carbon monoxide in the troposphere: implications for the tropospheric ozone budget. Journal of Geophysical Research 88 (C6), 3662-3670.

Harris, J.M., Kahl, J.D., 1990. A descriptive atmospheric transport climatology for the Mauna Loa Observatory using clustered trajectories. Journal of Geophysical Research 95, $13,651-13,667$.

Harris, J.M., Oltmans, S.J., 1997. Variations in tropospheric ozone related to transport at American Samoa. Journal of Geophysical Research 102 (D7), 8781-8791.

Harris, J.M., Oltmans, S.J., Dlugokencky, E.J., Novelli, P.C., Johnson, B.J., Mefford, T., 1998. An investigation into the source of the springtime tropospheric ozone maximum at Mauna Loa Observatory. Geophysical Research Letters 25 (11), 1895-1898.

Harris, J.M., Oltmans, S.J., Tans, P.P., Evans, R.D., Quincy, D.L., 2001. A new method for describing long-term changes in total ozone. Geophysical Research Letters 38 (24), 4535-4538.

Harris, J.M., Draxler, R.R., Oltmans, S.J., 2005. Trajectory model sensitivity to differences in input data and vertical transport method. Journal of Geophysical Research 110, D14109.

Helmig, D., et al., 2004. Boundary layer ozone production at South Pole. Eos Trans. AGU, 85(47), Fall Meet. Suppl., Abstract A21D-02.

Jaffe, D.A., 1991. Local sources of pollution in the Arctic from Prudhoe Bay to the Taz Peninsula. In: Sturges, W.T. (Ed.), Arctic Ozone Chemistry, in Pollution of the Arctic Atmosphere. Elevesier, Essex, England, pp. 255-287.

Jaffe, D., Price, H., Parrish, D., Goldstein, A., Harris, J., 2003. Increasing background ozone during spring on the west coast of North America. Geophysical Research Letters 30 (12), 1613.

Johnson, B.J., Oltmans, S.J., Vömel, H., Smit, H.G.J., Deshler, T., Kröger, C., 2002. Electrochemical concentration cell (ECC) ozonesonde pump efficiency measurements and tests on the sensitivity to ozone of buffered and unbuffered ECC sensor cathode solution. Journal of Geophysical Research 107 (D19), 4393.

Jonson, J.E., Simpson, D., Fagerli, H., Solberg, S., 2005. Can we explain the trends in European ozone levels? Atmospheric Chemistry and Physics Discussion 5, 5957-5985.

Komhyr, W.D., 1969. Electrochemical cells for gas analysis. Annales de Geophysique 25, 103-110.

Lamarque, J.-F., Hess, P., Emmons, L., Buja, L., Washington, W., Granier, C., 2005. Tropospheric ozone evolution between 1890 and 1990. Journal of Geophysical Research 110, D8304. 
Langenfelds, R.L., Steele, L.P., Cooper, L.N., Spencer, D.A., Krummel, P.B., Dunse, B.L., 2003. Atmospheric methane, carbon dioxide, hydrogen, carbon monoxide, and nitrous oxide from Cape Grim flask air samples analyzed by gas chromatography. In: Tindale, N.W., Derek, N., Fraser, P.J. (Eds.), Baseline Atmospheric Program Australia 1999-2000. Published for the Bureau of Meteorology and CSIRO Research, Melbourne, pp. 76-77.

Lefohn, A.S., Shadwick, D.S., 1991. Ozone, sulfur dioxide, and nitrogen dioxide trends at rural sites located in the United States. Atmospheric Environment 25A, 491-501.

Lelieveld, J., van Aardenne, J., Fischer, H., de Reus, M., Williams, J., Winkler, P., 2004. Increasing ozone over the Atlantic Ocean. Science 304, 1483-1487.

Lindskog, A., et al., 2003. Tropospheric ozone Research-TOR2, TOR-2 Final Report. In: Lindskog, A. (Ed.), EUROTRAC-2 ISS, GSF Research Center, Munich, Germany, pp. 1-34.

Logan, J.A., 1994. Trends in the vertical distribution of ozone: an analysis of ozonesonde data. Journal of Geophysical Research 99, 25,553-25,585.

Logan, J.A., 1999. An analysis of ozonesonde data for the troposphere: recommendations for testing 3-D models and development of a gridded climatology for tropospheric ozone. Journal of Geophysical Research 104, 16,115-16,149.

Logan, J.A., et al., 1999. Trends in the vertical distribution of ozone: a comparison of two analyses of ozonesonde data. Journal of Geophysical Research 104 (D21), 26,373-26,399.

Lovblad, G., Tarrason, L., Torseth, K., Dutchak, S., 2004. EMEP Assessment Part I: European Perspective, http:// www.emep.int. The Norwegian Meteorological Institute, Oslo, Norway, p. 5961.

McKenzie, R.L., Smale, D., Bodeker, G.E., Claude, H., 2003. Ozone profile differences between Europe and New Zealand: effects on surface UV irradiance and its estimation from satellite sensors. Journal of Geophysical Research 108 (D6), 4179.

Meyer, C.P., Ellsworth, C.M., Galbally, I.E., 1990. Ultraviolet absorption monitors for ozone in ambient air. In: Wilson, S.R., Ayers, G.P. (Eds.), Baseline Atmospheric Program Australia 1988. Published for the Bureau of Meteorology and CSIRO Research, Melbourne, pp. 28-37.

Moody, J.L., 1986. The influence of meteorology on precipitation chemistry at selected sites in the Eastern United States, Ph.D. Thesis, University of Michigan, Ann Arbor, 176pp.

Naja, M., Akimoto, H., 2004. Contribution of regional pollution and long-range transport to the Asia-Pacific region: analysis of long-term ozonesonde data over Japan. Journal of Geophysical Research 109, D21306.

Novelli, P.C., Masarie, K.A., Lang, P.M., Hall, B.D., Meyers, C.P., Elkins, J.W., 2003. Reanalysis of tropospheric CO trends: effects of the 1997-1998 wildfires. Journal of Geophysical Research 108 (D15), 4464.

Oltmans, S.J., 1991. Arctic ozone chemistry. In: Sturges, W.T. (Ed.), Pollution of the Arctic Atmosphere. Elsevier, Essex, England, pp. 185-215.

Oltmans, S.J., 1993. Climatology of Arctic and Antarctic tropospheric ozone. In: Niki, H., Becker, K.H. (Eds.), The Tropospheric Chemistry of Ozone in the Polar Regions, NATO ASI Series, vol. 7. Springer, Berlin, Heidelberg, pp. 23-40.
Oltmans, S.J., Levy II, H., 1994. Surface ozone measurements from a global network. Atmospheric Environment 28 (1), 9-24.

Oltmans, S.J., Hofmann, L., Harris, J.M., Komhyr, W.D., Kuniyuki, D., 1996. Tropospheric ozone during Mauna Loa Observatory Photochemistry Experiment 2 compared to longterm measurements from surface and ozonesonde observations. Journal of Geophysical Research 101 (D9), $14,569-14,580$.

Oltmans, S.J., et al., 1998. Trends of ozone in the troposphere. Geophysical Research Letters 24, 139-142.

Oltmans, S.J., et al., 2004. Tropospheric ozone over the North Pacific from ozonesonde observations. Journal of Geophysical Research 109, D15S01.

Prinn, R.G., 1988. Toward an improved global network for determination of tropospheric ozone climatology and trends. Journal of Atmospheric Chemistry 6, 281-298.

Richter, A., Burrows, J.P., Nuss, H., Granier, C., Niemeier, U., 2005. Increase in tropospheric nitrogen dioxide over China observed from space. Nature 437, 129-132.

Scheel, H.-E., 2003. Ozone climatology studies for the Zugspitze and neighboring sites in the German Alps. In: Lindskog, A. (Ed.), TOR-2 Final Report. EUROTRAC-2 ISS. GSF Research Center, Munich, Germany, pp. 134-139.

Schuepbach, E., Friedli, T.K., Zanis, P., Monks, P.S., Penkett, S.A., 2001. State space analysis of changing seasonal ozone cycles (1988-1997) at Jungfraujoch (3580 m above sea level) in Switzerland. Journal of Geophysical Research 106 (D17), 20,413-20,427.

Simmonds, P.G., Derwent, R.G., Manning, A.L., Spain, G., 2004. Significant growth in surface ozone at Mace Head, Ireland, 1987-2003. Atmospheric Environment 38, 4769-4778.

Smit, H.G.J., Straeter, W., 2004. Assessment of the performance of ECC-ozone sondes under quasi-flight conditions in the environmental simulation chamber: Experiences from JOSIE. In: Zerefos, C. (Ed.), OZONE, Proceedings of the XX Quadrennial Ozone Symposium, 1-8 June 2004, Kos, Greece, vol. I, Athens, pp. 105-106.

SPARC, 1998. Assessment of trends in the vertical distribution of ozone. In: Harris, N., Hudson, R., Phillips, C. (Eds.), SPARC Report No. 1 \& WMO Ozone Research and Monitoring Report No. 43, Geneva, 289pp.

Staehelin, J., Thudium, J., Buehler, R., Volz-Thomas, A., Graber, W., 1994. Trends in surface ozone concentrations at Arosa (Switzerland). Atmospheric Environment 28 (1), 75-87.

Tarasick, D.W., Fioletev, V.E., Wardle, D.I., Kerr, J.B., Davies, J., 2005. Changes in the vertical distribution of ozone over Canada from ozonesondes: 1980-2001. Journal of Geophysical Research 110, D02304.

Thoning, K.W., Tans, P.P., Komhyr, W.D., 1989. Atmospheric carbon dioxide at Mauna Loa Observatory 2: analysis of the NOAA GMCC Data, 1974-1985. Journal of Geophysical Research 94, 8549-8565.

Tiao, G.C., et al., 1990. Effects of autocorrelation and temporal sampling schemes on estimates of trend and spatial correlation. Journal of Geophysical Research 95, 20,507-20,517.

Vingarzan, R., 2004. A review of surface ozone background levels and trends. Atmospheric Environment 38, 3431-3442.

Winkler, P., 1988. Surface ozone over the Atlantic Ocean. Journal of Atmospheric Chemistry 7, 73-91. 